\title{
Novel eccentric corneoscleral donor preparation technique providing corneoscleral tectonic and central split corneal grafts for multiple recipients
}

\author{
Sigrid Roters ${ }^{1}$ - Alexander C. Rokohl ${ }^{1}$ - Ludwig M. Heindl ${ }^{1}$. Claus Cursiefen ${ }^{1,2}$
}

Received: 10 June 2021 / Revised: 26 September 2021 / Accepted: 24 October 2021 / Published online: 30 October 2021

(c) The Author(s) 2021, corrected publication 2022

\section{Key messages}

- Split cornea transplantation technique usually refers to using one donor cornea for two recipients by combining deep anterior lamellar keratoplasty (DALK) and Descemet membrane endothelial keratoplasty (DMEK) surgeries.

- The novel decentral donor eye preparation technique described herein combines central split cornea transplantation with peripheral tectonic corneoscleral grafting for up to three recipients using one single donor button.

- The decentral donor trephination technique using a 17.5-mm trephine should be the standard approach in donor eye preparation when block excision with tectonic corneoscleral graft is scheduled since the remainder of the cornea can be used for penetrating keratoplasty or combined DALK and DMEK reducing consumption of corneal donor tissue.

Dear Editor,

Today, split cornea technique is an established procedure and is mostly used for two recipients by combining deep anterior lamellar keratoplasty (DALK) and Descemet membrane endothelial keratoplasty (DMEK) surgeries [1-7]. However, for some surgical interventions including block excision with tectonic corneoscleral grafting, split cornea procedure is not planned regularly up to now $[5,8]$. In the run-up for this procedure, normally a donor cornea with a bigger scleral ring is gained. Nonetheless, the preparation of the tectonic graft for covering the corneoscleral defect after block excision results in a rest donor cornea transplant which

Sigrid Roters and Alexander C. Rokohl contributed equally, and both should be considered as first authors.

Alexander C. Rokohl

alexander.rokohl@uk-koeln.de

1 Department of Ophthalmology, Faculty of Medicine and University Hospital of Cologne, University of Cologne, Kerpener Straße 62, 50937 Cologne, Germany

2 Center for Molecular Medicine Cologne (CMMC), University of Cologne, Cologne, Germany is normally too small for further regular size penetrating keratoplasties (PKs) or combined DALK/DMEK surgeries. However, using a modified donor transplant trephination technique, a corneoscleral transplant for regular size keratoplasties can be gained, also after preparation of a tectonic graft for block excision. Herein, we describe shortly this novel donor preparation technique, the differences compared to the standard procedure, possible applications, and the advantages and disadvantages for the first time.

Commonly for standard donor preparation (i.e., corneal grafts for DMEK, DALK, or PK except block excision), most cornea banks perform a central scleral trephination using a trephine with $15.5 \mathrm{~mm}$ diameter (Fig. 1A) [9]. For a block excision with a tectonic corneoscleral graft, a donor transplant with a bigger scleral ring is necessary. Therefore, usually, a central donor eye trephination is performed using a $17.5-\mathrm{mm}$ trephine to gain a suitable corneoscleral grafting for this procedure (without regular size corneal splitting) (Fig. 1B). However, a decentral donor eye trephination also using a $17.5-\mathrm{mm}$ trephine results in a corneoscleral donor transplant (Fig. 1C) which can be used both for block excision with tectonic corneoscleral graft and regular size penetrating keratoplasty or combined DALK and DMEK. 

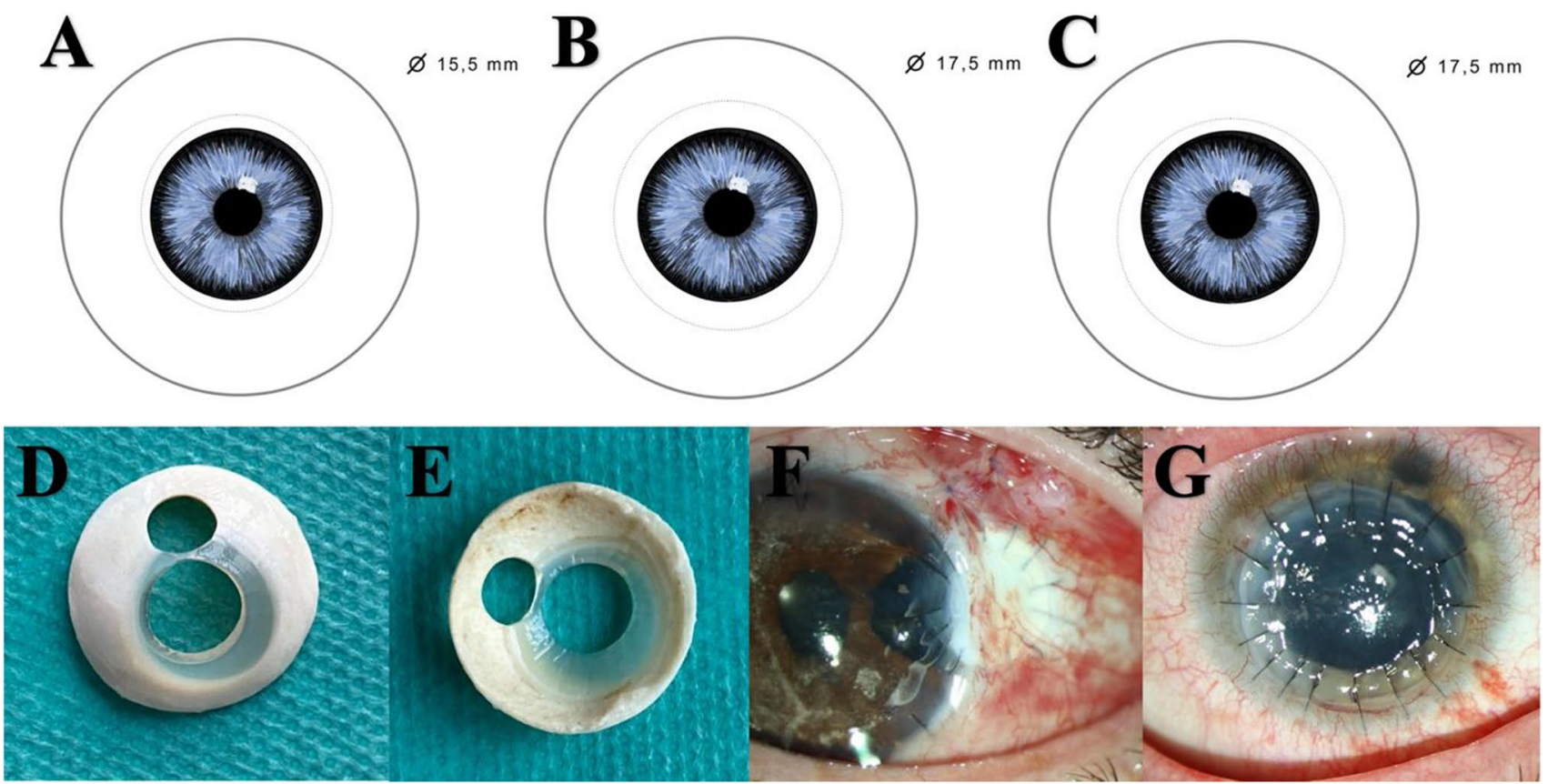

Fig. 1 Decentral trephination of the donor corneoscleral button allows combined use for normal central DMEK and DALK in addition to a peripheral tectonic graft for corneoscleral grafting. Conventional central trephination of the donor eye using a trephine with $15.5 \mathrm{~mm}$ diameter (A) and a larger trephine of $17.5 \mathrm{~mm}(\mathbf{B})$. Decentral eccentric donor trephination also using a $17.5-\mathrm{mm}$ trephine results in a bigger scleral area on one side of the donor transplant for up to 7.5-mm corneoscleral tectonic grafts $(\mathbf{C})$. In addition to this peripheral corneoscleral tectonic graft, a full 7.5 or $8 \mathrm{~mm}$ or

In particular, the decentral trephination results in a bigger scleral area on one side of the donor transplant (Fig. 1C). In our case, we gained a 5.2-mm-diameter corneoscleral tectonic graft in this area (Fig. 1D, E) and used it successfully for covering a defect after block excision of a ciliary body tumor (Fig. 1F). With this novel approach, a peripheral graft of up to $7.5 \mathrm{~mm}$ diameter can be created, while-in contrast to (conventional) central donor trephination - the rest of the decentrally trephined donor transplant is still big enough to gain an up to 8.0-mm (Fig. 1D, E) central corneal graft. These central corneal grafts can be used for a regular-sized penetrating keratoplasty (here after perforated corneal herpetic ulcer; Fig. 1G) or for combined DMEK and DALK.

This is the most important advantage of this novel preparation technique. A single donor cornea might be used for up to three recipients, thus reducing the need for corneal tissue and - at least in the long run-limiting corneal donor tissue shortage [10]. Our case suggests that this approach seems to be feasible. Nonetheless, several questions have to be addressed. In some rare cases, the described split cornea technique might not be feasible, for example, if the preparation of the corneoscleral graft for the block excision results-contrary to preoperative expectations-in a even larger diameter corneal graft can be gained for penetrating keratoplasty or combined DMEK/DALK (accidentally trephined minimal eccentric; D, E). Here, e.g., a 5.2-mm peripheral corneoscleral tectonic graft was used successfully for covering a $5 \mathrm{~mm}$ defect after block excision of a ciliary body tumor (first postoperative day, F), while a $7.5-\mathrm{mm}$ corneal graft was used for an uncomplicated penetrating keratoplasty after perforated herpetic ulcer (second postoperative day, $\mathbf{G )}$

too small corneal rest for the subsequent PK or combined DMEK and DALK. This might occur when a tectonic graft with a much larger diameter (i.e., $>7.5 \mathrm{~mm}$ ) is necessary for covering defects after block excision of, e.g., ciliary body tumors, appearing larger intraoperatively than expected. In addition, the use of one single donor transplant for up to three patients assumes a specialized ophthalmology center performing tumor and corneal surgery as well as having sophisticated logistics in the surgical theater. Usually, surgeries using material from one single donor button are planned on the same day. After corneoscleral tectonic grafting, the remaining graft is stored in a closed organ culture system containing $100 \mathrm{ml}$ minimal essential medium with $2 \%$ fetal calf serum, dextran, and antibiotics at $32{ }^{\circ} \mathrm{C}$ until preparation for keratoplasty. If it is not possible to perform the surgeries on the same day, the remaining donor material can be stored again in a closed organ culture system (maximum until the date of expiration). Therefore, also the eye bank needs sophisticated logistics including a functional documentation and labeling system.

Furthermore, these grafts have to be supplied by an external eye bank if the ophthalmology center is not having its own eye bank using this novel preparation technique. 
For the sake of completeness, this novel preparation technique is not necessary for all kinds of corneoscleral grafting. For very small corneoscleral defects, corneoscleral buttons arising after standard trephination for PK, DMEK, or DALK could be used instead of being discarded.

However, in conclusion, this novel preparation technique of eccentric donor button preparation offers the opportunity to reduce the consumption of corneal donor tissue. Therefore, this modified trephination technique should be the standard approach in corneal donor transplant preparation if a block excision with tectonic corneoscleral graft is planned.

Acknowledgements We thank our highly appreciated colleagues Sabine Hackbarth, Monika Linder, Tanja Oestreicher, Hans Günter Simons, Philomena A. Wawer Matos, Antonia Howaldt, and Adam Kopecky for providing their extraordinary support for this manuscript.

Funding Open Access funding enabled and organized by Projekt DEAL. Supported by the Gerok Program, Faculty of Medicine, University of Cologne (to A.C.R.), by the Cologne Clinician Scientist Program (CCSP), Faculty of Medicine, University of Cologne and funded by the German Research Foundation (DFG, FI 773/15-1) (to A.C.R), CMMC (A09; to C.C.), DFG FOR 2240 (www.for2240.de; to C.C and L.M.H.), and EU COST Aniridia (to C.C.). The sponsor or funding organization had no role in the design or conduct of this research. The authors have no further financial disclosures.

\section{Declarations}

Ethics approval and consent All procedures performed in this study involving human participants were in accordance with the ethical standards of the institutional research committee and with the 1964 Helsinki declaration and its later amendments or comparable ethical standards. No animal subjects were included in this study.

Conflict of interest The authors declare no competing interests.

Open Access This article is licensed under a Creative Commons Attribution 4.0 International License, which permits use, sharing, adaptation, distribution and reproduction in any medium or format, as long as you give appropriate credit to the original author(s) and the source, provide a link to the Creative Commons licence, and indicate if changes were made. The images or other third party material in this article are included in the article's Creative Commons licence, unless indicated otherwise in a credit line to the material. If material is not included in the article's Creative Commons licence and your intended use is not permitted by statutory regulation or exceeds the permitted use, you will need to obtain permission directly from the copyright holder. To view a copy of this licence, visit http://creativecommons.org/licenses/by/4.0/.

\section{References}

1. Heindl LM, Riss S, Bachmann BO, Laaser K, Kruse FE, Cursiefen C (2011) Split cornea transplantation for 2 recipients: a new strategy to reduce corneal tissue cost and shortage. Ophthalmology 118:294-301. https://doi.org/10.1016/j.ophtha.2010.05.025

2. Schaub F, Enders P, Cursiefen C, Heindl LM (2016) Split-cornea transplantation - a microbiologically safe approach? Graefes Arch Clin Exp Ophthalmol 254:1441-1442. https://doi.org/10.1007/ s00417-016-3324-z

3. Heindl LM, Riss S, Laaser K, Bachmann BO, Kruse FE, Cursiefen C (2011) Split cornea transplantation for 2 recipients - review of the first 100 consecutive patients. Am J Ophthalmol 152:523-532 e522. https://doi.org/10.1016/j.ajo.2011.03.021

4. Heindl LM, Riss S, Adler W, Bucher F, Hos D, Cursiefen C (2013) Split cornea transplantation: relationship between storage time of split donor tissue and outcome. Ophthalmology 120:899-907. https://doi.org/10.1016/j.ophtha.2012.11.012

5. Gadhvi KA, Coco G, Pagano L, Kaye SB, Ferrari S, Levis HJ, Parekh M, Romano V (2020) Eye banking: one cornea for multiple recipients. Cornea 39:1599-1603. https://doi.org/10.1097/ ICO.0000000000002476

6. Lie JT, Groeneveld-van Beek EA, Ham L, van der Wees J, Melles GR (2010) More efficient use of donor corneal tissue with Descemet membrane endothelial keratoplasty (DMEK): two lamellar keratoplasty procedures with one donor cornea. $\mathrm{Br}$ J Ophthalmol 94:1265-1266. https://doi.org/10.1136/bjo.2009. 171629

7. Schaub F, Cursiefen C, Heindl LM (2015) Retrospective Appraisal of split-cornea transplantation: an audit of 1141 donor corneas. JAMA Ophthalmol 133:1086-1087. https://doi.org/10.1001/ jamaophthalmol.2015.1684

8. Heindl LM, Koch KR, Hermann MM, Merkelbach-Bruse S, Schultheis AM, Wagener S, Buttner R, Mauch C, Schuler-Thurner B, Schuler G, Cursiefen C (2017) Block excision of iridociliary tumors enables molecular profiling and immune vaccination. Ophthalmology 124:268-270. https://doi.org/10.1016/j.ophtha.2016. 09.011

9. Bohnke M (1991) A new system for storing donor corneas. Klin Monbl Augenheilkd 198:135-137. https://doi.org/10.1055/s-20081045945

10. Drozhzhyna G, Gaidamaka TB, Cursiefen C, Bachmann BO, Matthaei M, Siebelmann S, Ostashevsky V, Ivanovska OV, Kogan BM (2020) Efficient use of corneal grafts through multimodal donor tissue splitting. Klin Monbl Augenheilkd. https://doi.org/ 10.1055/a-1165-2134

Publisher's note Springer Nature remains neutral with regard to jurisdictional claims in published maps and institutional affiliations. 